\title{
The Use of Learner Management System (MOODLE) in Promoting Teaching and Learning
}

\author{
Ayanda Pamella Deliwe \\ Faculty of Business and Economic Science, Nelson Mandela University, University Way, Summerstrand, 6019, South Africa
}

Received September 6, 2020; Revised November 17, 2020; Accepted November 25, 2020

\section{Cite This Paper in the following Citation Styles}

(a): [1] Ayanda Pamella Deliwe, "The Use of Learner Management System (MOODLE) in Promoting Teaching and Learning," Universal Journal of Educational Research, Vol. 8, No. 12B, pp. 8383-8392, 2020. DOI: 10.13189/ujer.2020.082644.

(b): Ayanda Pamella Deliwe (2020). The Use of Learner Management System (MOODLE) in Promoting Teaching and Learning. Universal Journal of Educational Research, 8(12B), 8383-8392. DOI: 10.13189/ujer.2020.082644.

Copyright@2020 by authors, all rights reserved. Authors agree that this article remains permanently open access under the terms of the Creative Commons Attribution License 4.0 International License

\begin{abstract}
The term e-learning was introduced in the 1990s with the emergence of new technology-based education where information was transferred via the internet. Most Universities have incorporated e-learning to enhance teaching and learning. This enhancement came with several challenges in developing countries. E-learning has been viewed as a positive initiative in Higher Education Institutions (HEIs) as it is said to improve opportunities for critical thinking, develop better problem-solving abilities and assist in the improvement of productivity and efficiency of employees. In other words, e-learning is one of the forms of building capacity as the advantages are not only limited to HEIs they go beyond the workplace as well. It is for this reason that researchers need to engage in continuous research on how to improve e-learning so it can be beneficial to universities. This article seeks to understand the Learner Management System (LMS) MOODLE use in enhancing teaching and learning. There are four research questions which the study seeks to address. In addressing the research questions a mixed-method approach was used where six participants at the University of Kwa-Zulu Natal were interviewed on one-on-one interviews and 501 questionnaires were collected from student participants. The results revealed that one of the main reasons why MOODLE was chosen as a LMS is that it is a free open system. Moreover, participants highlighted that the use of MOODLE is limited at the university as it is mostly used for uploading notes. Based on the information gathered from participants and literature some recommendations were given on how universities can utilise MOODLE to its best capacity.
\end{abstract}

Keywords E-Learning, MOODLE, Learner Management System, Teaching and Learning

\section{Introduction}

The term e-learning was introduced in the 1990s with the emergence of new technology-based education where information was transferred via the internet [9]. E-Learning is learning that is achieved using electronic media and it comprises all types of learning and teaching tools that are supported electronically [7]. Online learning is used for the enhancement of the education experience [45]. It is important to note that e-learning did not change the education system completely, it just enhanced it by introducing easier ways of teaching and learning. According to Queiros and de Villiers [41], e-learning was introduced in South Africa to reach the disadvantaged and side-lined students. This statement is however debatable, as the disadvantaged are currently those who are the most disadvantaged when it comes to e-learning, as they do not have the means to access the internet, or even a computer when they are away from the campus. According to Rezai-Rad, Vaezi and Nattagh [42], technology may contribute to solving problems with the possibility of ensuring the improvement of the delivery of services in developed and developing countries.

\section{Problem statement}

Shorey, Siew and Ang [47] hold that e-learning is the 
effective use of multimedia technology in the learning process and that it has gained popularity in teaching and learning. According to Shorey et al. [47], e-learning has the advantage of increasing the accessibility and distribution of educational material to students, as well as a shift from the teacher-centered education model to a student-centered model. There are however complications with e-learning in that some students feel isolated, as there is no face-to-face engagement with fellow students and lecturers, as well as students not being motivated enough to participate in e-learning in a home setting [47]. According to Hadullo, Oboko and Omwenga [20], recent studies have shown that through the integration of ICT in education as an introduction to e-learning, numerous challenges associated with the quality of learning have arisen. For example, Kenya is facing quality issues related to an inadequate ICT and e-learning infrastructure, high internet costs, financial constraints, lack of technical skills, lack of course support, as well as a lack of commitment from the teaching staff. These same challenges are faced in South Africa and are threatening the successful implementation of e-learning systems. Lim Tinio, Smith and Bhowmik [31] stated that there is a lack of research on digital learning in developing countries. This is one of the reasons why continuous research needs to be conducted to ensure that there is an improvement in the implementation of e-learning which will improve the promotion of teaching and learning in higher education institutions. There is a concern though, when authors refer to lack of research still as in 2018, is this true or maybe research has been done but it ever gets to the people who are in a position to act on it. This leads to a question, what happens to the research that is conducted and what is the purpose of conducting research. Is it just to publish?

\section{Purpose of the study and research questions}

The purpose of this study is to understand how LMS MOODLE is used in promoting teaching and learning and to gain an insight into how best higher education institutions can use MOODLE to its maximum capacity. The study is going to answer four critical questions:

- Why is MOODLE learner management system the preferred LMS at UKZN?

- How is MOODLE used at UKZN in promoting teaching and learning?

- How can UKZN ensure that they use MOODLE to its maximum capacity?

- What are the perceptions of students on the use of MOODLE?

\section{Analysis of recent research on Learner Management Systems}

Learning management systems (LMS) are flexible tools for universities in the learning and teaching environment globally [26]. Munoz et al. [35] defined LMS as a working environment that plays a supportive role in the management of content and academic processes for online and on-campus students and lecturers. According to Parathnandh, Sing, Lalloo, Pillay and Nadesanreddy [37], LMS makes it easier to monitor tools of material usage, to perform evaluation and testing online and to facilitate communication between learners and teachers. The LMS provides the academic staff and the students with the tools needed for the improvement of the learning process and management [49]. Ssekakubo et al. [38] stated that LMS as a learning tool is viewed as being the most basic and reliable tool for carrying out blended learning and is the starting point of web-based programs. Numerous LMSs are used by South African universities, including WebCT (World Wide Web Course Tool), Sakai and MOODLE [5]. UKZN introduced the LMS MOODLE in 2010 and it can be found on the UKZN website as e-learning@ukzn. This LMS is available to students and lecturers and is mainly used by lecturers to upload all their learning and teaching materials and to initiate discussion forums [44]. There are several LMS and they are aTutor, eliademy, and Moodle. According to Lengyel et al. [30], aTutor promises that it is easy to install, provides good documentation and has strong potential for development, as well as a development team that is committed to maintaining high standards. It allows for students to learn in a user-friendly environment where they utilise the communicative tools that are part of the software [32]. According to Men, Liu and Han [34], the introduction of ATutor in the education field could lead to feature-rich eLearning management platform settings and plays a role in supporting classroom teaching in the information age. Sotiris Makrygiannis and Sergey Gerasimenko founded Eliademy in 2012 in Finland [54]. Eliademy is an LMS that could include several teachers for the course. It is said to have good tools for interaction, be easy to use, have relevant privacy controls, provide a quick registration process and have a user-friendly layout [4]. According to Perwonegoro and Syafei [39], Eliademy provides freedom for users to be able to design or produce tailor-made material rather than using the available materials. LMS Moodle will be explained briefly below.

\section{MOODLE}

Modular Object-Oriented Dynamic Learning Environment (MOODLE) is an open-course management system that is also known as an LMS. MOODLE was introduced to assist lecturers in creating online courses that focus on interaction and collaboration, with the first version of MOODLE being released in August 2002 [37]. According to Costello [14], MOODLE was started by a computer science graduate, Martin Dougiamas, in a computer server room of an Australian university in 1999. Ever since the first version of MOODLE was released, its 
source code has been available and open to anyone. The MOODLE platform is a type of e-learning platform used in the teaching process [23]. According to Coll and Treagust [13], MOODLE gives students significant scope for independence, which in turn promotes learning, social interaction and the social construction of knowledge. Students' learning outcomes can be achieved through integrated learning using MOODLE [13]. MOODLE is available on Andriod and iOs platforms [43]. There are numerous other support tools for distance learning that are similar to MOODLE, namely eCollege, ATutor, Derire2Learn and Dokeos [29]. According to Chicioreanu and Cosma [7], MOODLE provides access to several resources for academic staff, such as:

- URL link to a web page; text and images in the course sections can be introduced through labels/messages; an IMS content pack that allows for visualization within the course of content packs and is in accordance with the specifications of IMS content packaging; a downloadable document that can be utilized and a web page that makes it possible to edit within the course. Chung and Ackerman [15], Jakshylykov and Nurmatov [24], Jebari, Boussedra and Ettouhami [25] and Zainuddin, Idrus and Jamal, [53] hold that MOODLE is a network for interaction between academic staff and students and numerous resources and activities are offered, namely those listed below.

- Forums: where students and academic staff can engage through discussions and the sharing of ideas. Chat: is available for a certain day or week (specific time). Wiki: comments by the academic staff, space for collaborative work. Glossary: for creating and maintaining a list of definitions. Groups: students can be separated into groups based on their chosen modules of study. Assignment: allows the academic staff to collect work from students. Lesson: questions can be asked for evaluation purposes. Database: custom field records, for sharing and collection of data. Workshop: student evaluation, peer assessment. Quiz: in the form of multiple-choice, true or false questions.

If students use MOODLE, they have the advantage of accessing a wide range of educational material to interact with other students and academic staff [25]. Table 1 highlights the advantages and disadvantages of using

\section{MOODLE.}

Table 1. Advantages and disadvantages of MOODLE

\begin{tabular}{|c|c|}
\hline $\begin{array}{l}\text { Advantages of Moodle presented by } \\
\text { Chicioreanu and Cosma [11] }\end{array}$ & $\begin{array}{c}\text { Disadvantages of Moodle } \\
\text { presented by Petrovici and } \\
\text { Ciobanu [40] }\end{array}$ \\
\hline $\begin{array}{l}\text { Academic staff and student } \\
\text { interaction is in real-time and } \\
\text { students receive answers quickly. }\end{array}$ & $\begin{array}{l}\text { There is no real guarantee } \\
\text { that the students studied } \\
\text { what they were supposed to } \\
\text { study. }\end{array}$ \\
\hline $\begin{array}{l}\text { on MOODLE. Chung } \\
\text { Ackerman (2015) } \\
\text { assertion in that } \\
\text { MOODLE } \\
\text { students } \\
\text { this } \\
\text { find } \\
\end{array}$ & $\begin{array}{l}\text { It is difficult for academic } \\
\text { staff to assess the abilities } \\
\text { and competencies of } \\
\text { students when it comes to }\end{array}$ \\
\hline $\begin{array}{l}\text { The creation of backup copies and } \\
\text { information restoration is simple. }\end{array}$ & $\begin{array}{l}\text { creativity and critical } \\
\text { thinking. }\end{array}$ \\
\hline $\begin{array}{l}\text { Keeping a register of grades and } \\
\text { downloading to spreadsheets. }\end{array}$ & $\begin{array}{l}\text { Solving tasks can be } \\
\text { achieved by copying and } \\
\text { pasting. }\end{array}$ \\
\hline $\begin{array}{l}\text { Ease of access to archived } \\
\text { information from other academic } \\
\text { staff. }\end{array}$ & $\begin{array}{l}\text { There are no guarantees of } \\
\text { the results of the final tests. }\end{array}$ \\
\hline
\end{tabular}

According to Jakshylykov and Nurmatov [24], a study was conducted at the international Tataturk Ala-Too University (IAAU) on the integration challenges of university and information management systems (UIMS) and MOODLE. Part of the results revealed that the MOODLE system holds several challenges, as listed below.

- There is a lack of resources and infrastructure; there are no experts in an integration area and no training on MOODLE; awareness of e-learning is little and some students still prefer face-to-face learning as opposed to e-learning. UKZN only adopted MOODLE in 2010. Sibanda and Donnelly [44] hold that as much as MOODLE has benefits for universities for teaching and learning, it also has problems, as MOODLE does not offer additional support to students, only the demonstration of lecturers encouraging students to use the online platform. Patel and Patel [38] conducted a study that included the comparison of various learner management systems. These systems included MOODLE, ATutor, Eliademy and Forma LMS. The results revealed that MOODLE was the more effective and efficient learner management system when compared to the other three LMSs. 

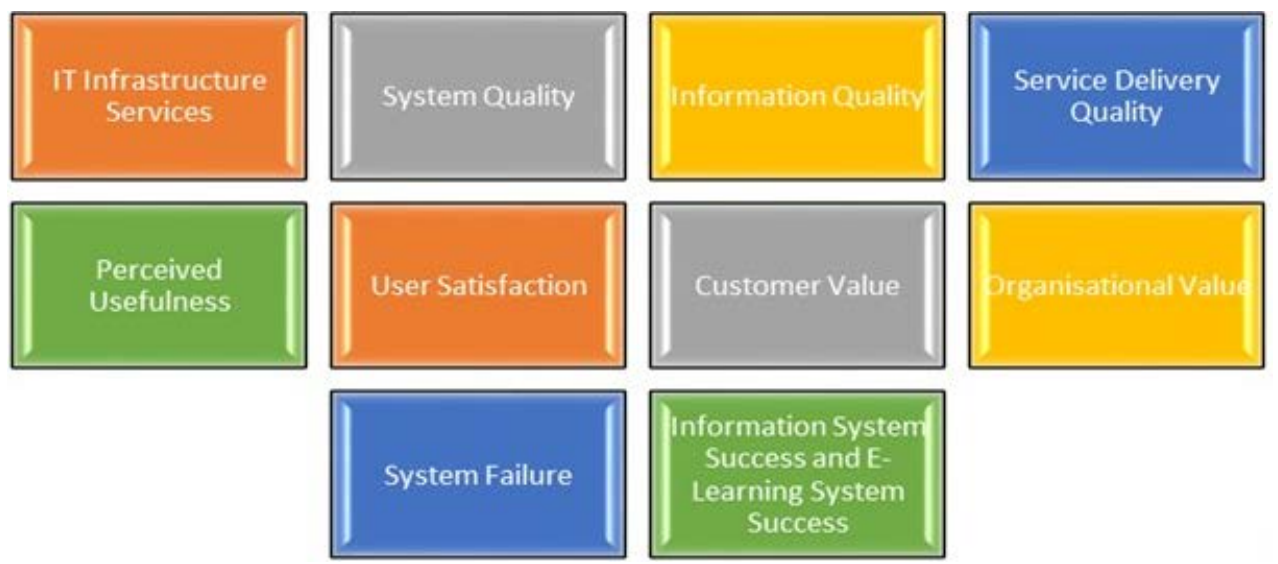

Source: Adapted from Al-Sabawy [2]

Figure 1. Evaluation methodology model

\section{Using evaluation methodology model to understand students' perceptions on the use of Moodle}

This study applied the evaluation methodology model for measuring the success of e-learning systems. Hassanzadeh, Kanaani and Elahi [21] highlighted the importance of a model for measuring the success of e-learning systems. Al-Sabawy [2] proposed the model presented below comprising ten variables.

\section{Materials and Methods}

In collecting data to answer the research questions mixed methods were adopted where both qualitative and quantitative research methods were adopted. According to Oates [36], qualitative data is mainly used by critical and interpretive researchers. When investigating a specific issue in-depth, a case study is the most appropriate method to use [55]. A case study assumes that the case being examined is atypical. The case that the researcher selects is the basis for an in-depth, thorough and holistic examination of aspects that the researcher wishes to find out about [27]. This study adopted a case study where UKZN was used as a case study.

The researcher conducted one-on-one interviews with 6 participants made up of two support staff members, two management and two members who belong to the accreditation bodies at UKZN. The criteria that the researcher used for selecting the participants were stakeholders who use MOODLE regularly.

Quantitative research is based on positivist or post-positivist philosophical assumptions. Numerical data are collected and analysed using statistics to determine the relationships between variables [17]. When collecting the quantitative data, the researcher used structured surveys, where each questionnaire consisted of a formal list of questions asked of all participants. These questionnaires were in the form of a web-based survey, (QuestionPro), and it was sent to participants via the UKZN notice system. There were 501 responses received from student participants.

To analyze data for qualitative data, the researcher used themes and patterns. According to Oates [36], patterns, visuals and themes are deemed to be relevant in a qualitative study. Cohen et al. [12] indicated that creating themes and patterns can be referred to as coding. Coding can be achieved by grouping the text that is about a specific idea or thought. With this type of analysis, the researcher can find similar themes.

The researcher used an online survey system (QuestionPro) and data were exported to excel and Statistica for analysis.

\section{Results}

The findings of the study led to two themes being identified from the qualitative data collection in answering the research questions. Theme one is the reason for the introduction of MOODLE at UKZN and theme two is the utilisation of MOODLE at UKZN and how it can be used to its maximum capacity. The quantitative results from the questionnaires distributed to students are also given.

\section{The reason for the introduction of MOODLE at UKZN}

\section{Theme 1: Need for learner management system}

The reason behind the introduction of MOODLE at UKZN is that the university needed an LMS. There was a department at the university that started using MOODLE on their own. It was the College of Humanities. They were using it for students to distribute notes and started teaching a little bit. Eventually, the University Teaching and Learning had asked for a LMS system; and since MOODLE was being used by the College of Humanities, they decided to use MOODLE system at UKZN.

\section{Theme 2: User-friendly blended learning system}

MOODLE was instilled in the mid-2000s which was 
available for anyone to use it. UKZN decided to officially adopt MOODLE in 2009 and it launched in 2010 beginning of the year. A study of different learner management systems was conducted and from that study, MOODLE was chosen because it is free and user-friendly. It was a sensible choice. There was a need for blended learning which is why a learner management system was investigated and introduced. UKZN needed an alternative way of communicating with students apart from traditional face to face learning so MOODLE was introduced as a form of blended learning. There is a team of developers all over the world who are adding new features to MOODLE

\section{Theme 3: Posting of study material online}

MOODLE was introduced for electronic learning. It was to allow for the interface between the students beyond the classroom. MOODLE was introduced for academics to post lecture notes which is for students to access online at their convenience. MOODLE was introduced as an enhancement tool to facilitate learning and to bring the instructor closer to the students and to help in managing numbers. As technology advanced the university has found easier ways of handling the work using MOODLE. MOODLE assists in doing work more effectively and efficiently.

\section{Theme 4: Platform for student's feedback}

Moodle was introduced for various reasons including it being introduced as an interim student feedback system which is a platform for student feedback. MOODLE was started as there was a demand for students to have this kind of technology. It was introduced for students to engage with other students and lecturers online.

\section{The utilisation of MOODLE at UKZN}

\section{Theme 1: Storing lecture notes}

A large portion of MOODLE is used for storing lecture notes. The university is currently trying to make it more of a teaching tool as there is the training of staff on how to do quizzes on MOODLE, how to carry out discussions as the aim is to make it more of an interactive system. MOODLE can be used as a teaching tool. There are discussion forums where students engage with students and lecturers. The lecturer will put up a discussion question and students will respond.

\section{Theme 2: Challenges of lecturers in using Moodle}

The lecturers have a challenge in that there is a whole lot of functionalities on MOODLE which they are not aware of and if they are not sure how they can use these features. These are not used because there is a lack of support for lecturers and they do not know these features. New things are scary to people. Lecturers need exposure to MOODLE. It is not easy to teach the advanced features to lecturers because those would need one-on-one sessions as each academic has specific needs. There is a need to sit down with lecturers to find out what their needs are, including what their technology needs and problems are so that they can be provided with that kind of support. The problem is there is no human capacity to do that. So basically, the current support that is available for lecturers is very basic level which just focuses on the basic use of MOODLE.

\section{Theme 3: Engagements}

MOODLE is used for a lot of things in the teaching and learning domain. It is a communication tool, used for uploading notes, discussion groups. MOODLE is used for random grouping of students. From engagements with other academics on the use of MOODLE they use it in different ways and it is not fully utilized but there are academics to try to use most of the functions of MOODLE. The assessment tool on MOODLE is not utilized and the participant would like to see more of that as MOODLE would be quick and fast in marking of student's assessments."

\section{Theme 4: Assessments}

MOODLE is used for assessment purposes through quizzes for certain modules not all. It is used to some degree as a replacement where students don't engage as much in lecture classes because they know that the notes will be available on MOODLE. Information is translated into IsiZulu and is available on the MOODLE system. There are plans to have two other language translations (Afrikaans and Sesotho) but at this stage, there is nothing concrete. This initiative is driven by the language office. MOODLE is not used to its maximum capacity. There are course outlines that have become mandatory for the lecture notes to be uploaded to MOODLE but not all of them. MOODLE can be used as a learning tool. The academics can use MOODLE to develop their evaluation or feedback online form apart from Quality Promotion and Assurance (QPAs) evaluation and it will assist them in understanding how the students feel about the modules and how best they can improve modules continuously."

\section{Theme 5: Notice system}

Currently, MOODLE is mainly used as a notice system rather than learning; that was not the intention behind it as it is currently used for posting material rather than a teaching tool. Some academics do use it for teaching but very few use it for discussions. The main reason why it is currently used for is uploading lecture notes and as a notice system. MOODLE is not used to its maximum capacity as more could be done for example there is no clarity if MOODLE can handle podcasts where the academics can post videos of lectures online for students. This was more specifically needed during the \#feesmustfall movement in 2016 where due to protests 
lectures were suspended for a while and if the podcast was working students could have been able to access the lecture anywhere anytime even though students were not physically present at the university they were going to benefit. In the participants' opinion, the system cannot accommodate the podcast. Another reason is that some academics do not understand the advantages of using MOODLE. There were however interactions with academics before MOODLE was introduced interactions in terms of seminars and workshops but the problem is that most academics do not attend such making it difficult to get their input.

\section{Perceptions of students on the use of Moodle}

Data collected from students revealed information about students' perceptions of the IT infrastructure at UZKN. Overall, the results were positive, as most students (45.14\%) agreed that the IT infrastructure is in place. However, 147 students were neutral in answer to the statement "The ICS division enables me to receive and exchange information and knowledge with lecturers and other students by using electronic linkages and software applications”, with only 60 students disagreeing with the statement.

The test of system quality revealed positive results and most students agreed that the system is of good quality. One of the main reasons identified from the results that led to this conclusion of system quality is that most students responded positively to "I find the MOODLE system easy to use and I find the MOODLE system easy to learn". Over $80 \%$ of the students responded positively to these statements. However, over $30 \%$ of the students answered between neutral and strong disagreement with the following two statements. "The MOODLE system always does what it should" and "The MOODLE system requires only the minimum number of fields and screens to achieve a task". This should not be taken lightly as it indicates that there is a group of students who are not satisfied with the system quality.

The quality of information offered by the MOODLE system was rated as high by students, as an average of $75 \%$ of the students agreed. The statements that were rated highly by the students were, "The information from the MOODLE system is easy to understand" and "The information I need from the MOODLE system is always available to me". Several students did not concur with the statement that "The information I need from the MOODLE system is always available to me", as 151 students answered neither agree/nor disagree and strongly disagree.

The majority of the students rated service delivery quality highly, as they agreed and strongly agreed with most statements. There were several concerning statements where more than $40 \%$ of the students were neutral and in disagreement and strong disagreement and these statements were: "MOODLE makes lectures, materials and feedback available within a suitable time frame", "I feel my information as a student is protected on MOODLE", "MOODLE is convenient for me to change a curriculum", "MOODLE allows me to engage in online discussions with other students", "MOODLE allows me to discuss issues with my lecturers", "MOODLE assists me with administrative challenges, such as unmarked assignments and the way forward".

The perceived usefulness of MOODLE by students was more favourable with the statements "Using the MOODLE system makes it easier for me to do my studies" and "The MOODLE system is useful to me in my studies", where over $70 \%$ of the students strongly agreed and agreed with the statements. The only two worrying statements to which attention needs to be paid are "MOODLE improves my study performance" and "MOODLE helps me to accomplish my tasks more quickly", as approximately $30 \%$ of the students were not in agreement with these statements, including students who were neutral about the statements.

Students seem to be happy with the MOODLE system, as over $70 \%$ of the students responded positively to all the statements: "If I had to choose between doing my studies online and face-to-face, I would choose online", "I am satisfied with my decision to study at a university that is using MOODLE" and "I am satisfied with the performance of the MOODLE system". What is critical to note is that more than $40 \%$ of the students were neutral, strongly disagreed and disagreed with the statement "If I had to choose between doing my studies online and face-to-face, I would choose online".

Students had to respond to questions about the value MOODLE adds for them as stakeholders in the university. The response was reasonably positive, as over $60 \%$ of the students responded positively.

The main statements about which most students were neutral, including "I believe that with MOODLE I have received value for money" and "MOODLE has assisted me to gain an understanding of concepts and principles in my study area that I do not believe I would have gained without MOODLE".

\section{Discussion}

To answer the questions, this information was gathered from literature and participants. Firstly, the LMS was introduced in answer to the demand for technology and as an enhancement tool. According to Bystrova et al. [9], e-learning was introduced due to the emergence of technology. Online learning enhances education and learning experience [10]. Hidayat [22] holds that there is a demand for electronic learning readiness in global life because of globalisation. There is a way in which the influence of globalization can be reduced, that is, to 
improve the education system. Hidayat [22] argued that using media in teaching and learning could result in the generation of interests, motivation, desires and stimulation of learning activities and enhancement of the learners' psychological state. The reason for the introduction of e-learning being the demand for technology highlighted by the participants is that it is good enough to introduce e-learning. What about the needs of the users and how they fit into the technology demands?

Secondly, MOODLE is chosen as a LMS at UKZN, because MOODLE is free and user-friendly. According to Khoza [28], MOODLE is free open-source software that users can download without needing permission or a license to do so. Khoza [28] elaborated by stating that most learners find MOODLE easy to use. Zainuddin et al., [53] also mentioned that MOODLE is a free open-source platform. The authors added that the use of this platform is usually motivated by the ease of adaptability, its simplicity and the open-source configuration. The ease of use of technology is linked to intrinsic motivation, where the quality of the tool is important [6]. Cheung, Chan, Brown and Wan [10] added that knowing how to use the technology plays a significant role in the perceptions of the users' ease of use. In introducing MOODLE based on the fact that it is a free open source platform, one should not forget about the other costs that are associated with the use of MOODLE including but not limited to; the cost of infrastructure and data.

Thirdly, participants indicated that the LMS used at UKZN is mainly used for uploading notes, obtaining students' feedback through evaluations, discussion forums and for students to access study material online at their convenience. Kabassi et al. [26] mentioned that the main tools that LMS is used for are: asynchronous and synchronous communication; content development and delivery and formative and summative assessment. Asynchronous and synchronous communication includes forums, chats and email. Content development and delivery include links to internet resources, learning objects, learning resources and files. Formative and summative assessment includes the tools that are utilised for self-evaluation, such as multiple-choice questions. According to participants in this study, MOODLE is not being used to its maximum capacity, as there are numerous other functions available on MOODLE that most academics do not use, such as assessment tools. There is not enough engagement and discussion on MOODLE. Zainuddin et al., [53] indicated that the MOODLE platform provides numerous capabilities that are not used to their full capacity. MOODLE was created to assist in the creation of online courses to focus on interaction and collaboration [37]. Currently, UKZN is not fully utilising MOODLE and is not benefiting fully from MOODLE [11]. This is very much similar to the literature review findings and the question is why is this still the case even after so much research being done and highlighting these issues.

Fourthly, when using the evaluation methodology model to understand the perception of students on the use of Moodle students, overall perceptions were positive but there are a few things to note. One of the main concerns of students that was revealed by the empirical qualitative and quantitative study was the security of their information on MOODLE. According to Durairaj and Manimaran [18], challenges relating to technical security issues are problematic and lead to constraints when using technology. Bose and Sarddar [8] emphasised the importance of ensuring the smooth and secure integration of students' requirements and the protection of the material. According to Sheikhtaheri et al. [46], when a system performs with speed and reasonability, it can be concluded that the system is flexible and reliable. The system was seen by most participants in the study as reliable and flexible. The flexibility of the system is when the system can adapt to the changing environment and demands of users [1]. What is of concern is that $30 \%$ of the ICS students remained neutral and in strong disagreement about the statements about system quality. According to Mai [33], information quality depends on the context, which needs to be understood. One of the main concerns of the participants was information availability. To measure service delivery, the SERVQUAL scale was used (Wong and Huang, 2011). SERVQUAL includes five service quality dimensions, namely reliability, assurance, tangibles, empathy and responsiveness. Through measurement of service delivery quality, the participants were concerned with lecture materials and feedback availability, convenience in curriculum changes and assistance with administrative challenges. Al-Debei [1] and Tarhini et al. [50] emphasised that perceived ease of use is related to the perceived usefulness and system usage. Just over 15\% of participants felt different and were not positive about the perceived usefulness. According to Al-Samarraie et al. [3], this necessitates that higher education institutions must improve and enhance the utility value (helpful e-learning tasks) and information quality, as this will increase the users' perceptions of the usefulness of the system. Most participants responded positively to statements related to the contributing factors with the security factor being of concern. The qualitative interview results also highlighted the concerns of users about the issue of security of their information on the MOODLE system. Freeze et al. [19] indicated that a user satisfaction test should be undertaken to measure the success of the interaction between users and the information system. Weinstein and McFarlane [51] mentioned that for customers' needs to be met, service providers must go the extra mile and deliver more than just enough to meet the customers' basic needs. Some participants are concerned about their value for money. 


\section{Conclusions}

There are many reasons for institutions introducing e-learning as part of their teaching and learning. The feedback from participants about the introduction of MOODLE at UKZN offers a broader understanding of why the university chose to introduce MOODLE. These reasons include the need for: a learner management system; blended learning; a students' feedback system; an interface between students and lecturers beyond the classroom and an enhancement tool. The other reason as to why MOODLE, as opposed to other learner management systems, is the fact that MOODLE is a free open source network. According to Patel and Patel [38], compared with other LMS, MOODLE was the most favourable one in terms of the performance of the features. MOODLE has many different functions that can be used by universities in their teaching and learning. It was however noted that at UKZN MOODLE is used mostly for uploading notes and not as a teaching tool. This information was revealed through the qualitative study that was conducted with participants.

There are several recommendations which are suggested as a way forward and these are:

- The participants raised the issue of there being limited support for academics on how to use MOODLE. This could be the reason why MOODLE is not used to its maximum capacity. The university can invest in ensuring that academics are properly trained on how to use all functions of MOODLE so they can understand how beneficial MOODLE is for them.

- There is concern that with academics there is no one method that fits all as they come from different colleges with different needs. It is for this reason that during the training of academics, their needs are understood so the instructor can address them specifically indicating how MOODLE will be of benefit to each academics' specific needs.

- Some of the participants indicated that MOODLE could be useful in peer assessments as students can engage in MOODLE and learn from each other. These are the tools that the university needs to pay attention to and ensure that they are used.

- It is further recommended that scholars should do research with a purpose, not just to publish because if that is the case the research is meaningless as it will not add value to the development of countries and the world. Meaningful research is the research that will be used to inform policies and in that way, the research results will not always be similar as years go by.

- Awareness among the academic community needs to be created about the benefits associated with e-learning.

- Internet accessibility and stability should be improved.
- Increased university management support for the adoption and use of e-learning is advised, such as financial and infrastructural support.

\section{REFERENCES}

[1] Al-Debei, M.M., 2014. The quality and acceptance of websites: an empirical investigation in the context of higher education. International Journal of Business Information Systems, Vol 15, No. 2, pp.170-188.

[2] A.Y. Al-Sabawy, A. Cater-Steel, J. Soar, 2013. Measuring e-learning systems success. Doctoral dissertation, University of Southern Queensland.

[3] H. Al-Samarraie, B.K. Teng, A.I. Alzahrani, and N. Alalwan, 2017. E-learning continuance satisfaction in higher education: a unified perspective from instructors and students. Studies in Higher Education, Vol 43, No. 11, pp. 1-17.

[4] H. Annala, S. Fopma and M. Leikomaa. Building an International, Cross-disciplinary, Collaborative Online English Course Focusing on Advanced Listening and Speaking Skills and Cross-cultural Communication. International Journal for Educational Media and Technology. Vol 10, No. 2, pp. 3-7, 2017.

[5] E. Bagarukayo and B. Kalema. Evaluation of eLearning usage in South African universities: A critical review, International Journal of Education and Development using Information and Communication Technology (IJEDICT), Vol 11, No. 2, pp.168-183, 2015.

[6] K. Bandlow, and S. Buckley. ICT Tools Usage's Effectiveness by Communities of Practice in Promoting Knowledge Management Innovation. In International Conference on e-Learning. Academic Conferences International Limited. pp. 21-25, 2016.

[7] G. Blackburn. In my end is my beginning: E-Learning at the crossroads. Tojet: The Thurkish Online Journal of Educational Technology, Vol 15, No. 3, pp.87-97, 2016.

[8] R. Bose and D. Sarddar, 2017. Developing a Secure Mode for Hybrid Distribution of University Course Learning Materials. International Journal of Computational Intelligence Research, Vol 13, No. 8, pp.2075-2093.

[9] T.Y. Bystrova, V.A. Larionova, M. Osborne and A.M. Platonove. Introduction of open e-learning system as a factor of regional development. R-Economy. 2015. Vol. 1. No. 4, pp. 587-596, 2015.

[10] G.Cheung, K. Chan, I. Brown and K. Wan. Teachers' Knowledge and Technology Acceptance: A Study on the Adoption of Clickers. In International Conference on e-Learning 2-3 June 2016 Universiti Sains Islam Malaysia (USIM) Kuala Lumpur Malaysia. Academic Conferences International Limited. pp. 46-51, 2016.

[11] T.D. Chicioreanu and I. Cosma,.I am a teacher in the digital era. What to Chhose: Google classroom or MOODLE? In The International Scientific Conference eLearning and Software for Education 27-28 April 2017 Bucharest. Vol 2, 
No. 1, pp. 310-315. "Carol” National Defence University, 2017.

[12] L. Cohen, L. Manion. And K. Morrison. Research methods in Education. 7th Edition. New York, USA: Routledge, 2011.

[13] S.D. Coll and D. Treagust. Blended learning environment: An approach to enhance students learning experiences outside school (LEOS). MIER Journal of Educational Studies, Trends and Practices, Vol 7, No. 2, pp. 121-134, 2018.

[14] E. Costello. Opening up to open source: looking at how MOODLE was adopted in higher education. Open Learning: The Journal of Open Distance and eLearning, Vol 28, No. 3, pp.187-200, 2013.

[15] C. Chung and D. Ackerman. Student reactions to classroom management technology: learning styles and attitudes towards moodle. Journal of Education for Business, Vol 90, No. 4, pp. 217-223, 2015.

[16] J.W. Creswell. Educational research: Planning conducting and evaluating quantitative and qualitative approaches to research. Upper Saddle River, NJ: Merrill/Pearson Education, pp. 1-9, 2002.

[17] J.W. Creswell, 2009. Research Design: Qualitative, Quantitative and Mixed-Methods Approaches. California, USA: SAGE Publications.

[18] M. Durairaj and A. Manimaran, 2015. A study on security issues in cloud based e-learning. Indian Journal of Science and Technology, Vol 8, No. 8, pp. 757-765.

[19] R.D. Freeze, K.A. Alshare, P.L. Lane and H.J. Wen, 2010. IS success model in e-learning context based on students' perceptions. Journal of Information Systems Education, Vol 21, No. 2, pp.172-184.

[20] K. Hadullo, R. Oboko, and E.Omwenga. Status of e-learning Quality in Kenya: Case of Jomo Kenyatta University of Agriculture and Technology Postgraduate Students. The International Review of Research in Open and Distributed Learning, Vol 19, No. 1, pp. 138-160, 2018.

[21] A. Hassanzadeh, F. Kanaani and E. Elahi, 2012. A model for measuring e-learning systems success in universities. Expert Systems with Applications, Vol 39, No. 12, pp. 10959-10966.

[22] A.N. Hidayat. E-Learning Implementation in Islamic Education Innovation. HUNAFA: Jurnal Studia Islamika, 14(1), pp.17-36, 2017.

[23] M.G. Ianos and G.C. Oproiu. Moodle platform in learning: Students voice," In The International Scientific Conference eLearning and Software for Education. Vol 2, pp.379-386. “Carol I” National Defence University, 2014.

[24] J.J. Jakshylykov and N.A. Nurmatov. Integration Challenges of University and Information Management System (UIMS) to Moodle. Интеграция образования, Vol 20, No. 2, pp. 158-163, 2016.

[25] K. Jebari, F. Boussedra. and A. Ettouhami. Teaching "Information Systems Management" with MOODLE. International Journal of Emerging Technologies in Learning, Vol 12, No. 4, pp. 4-16, 2017.

[26] K. Kabassi, I. Dragonas, and A. Ntouzevic-Pilika. Learning management systems in higher education in Greece: Literature review. In Information, Intelligence, Systems and Applications (IISA) 6th International Conference 6-8 July Corfu Greece. pp. 1-5, 2015

[27] J.A Khan. Research methodology. APH Publishing Corporation, 2011.

[28] S.B. Khoza. From the Other Side of MOODLE/Technology in Education of Postgraduate Students' Reflections. ICEL2016 Proceedings of the 11th International Conference on e- Learning 2-3 June Kuala Lumpur Malaysia. pp. 79-86, 2016.

[29] J.A. Lara, D. Lizcano, M.A. Martinez, J. Pazos and T. Riera. A system for knowledge discovery in e-learning environments within the European Higher Education Area-Application to student data from Open University of Madrid, UDIMA. Computers \& Education, Vol 72, pp. 23-36, 2014.

[30] P. Lengyel, M. Herdon and R. Szilágyi. Comparison of Moodle and ATutor lmss. Summer University on IT in Agriculture and Rural Development. pp. 21-28, 2006.

[31] C.P. Lim, V.L Tinio, M. Smith and M.K. Bhowmik. Digital learning for developing Asian countries. Routledge International Handbook of Schools and Schooling in Asia. pp. 369-381, 2018.

[32] Z. Lofti, N. Gazerani and F.H.M Nasaruddin. Collaborative Learning Software for Secondary School: ATutor. In Global Learn. Association for the Advancement of Computing in Education (AACE). pp. 1038-1045, 2010.

[33] J.E. Mai, 2013. The quality and quantities of information. Journal of the Association for Information Science and Technology, Vol 64, No. 4, pp. 675-688.

[34] H. Men, J. Liu and J. Han, December. Applied Research on Atutor. In Proceedings of the 2009 International Conference on E-Learning, E-Business, Enterprise Information Systems, and E-Government, pp. 107-110. IEEE Computer Society, 2009.

[35] A. Munoz, J. Lasheras, A. Capel, M. Cantabella and A. Caballero. OntoSakai: On the optimization of a Learning Management System using semantics and user profiling. Expert Systems and Applications, Vol 42, No. 15, pp. 5995-6007, 2015.

[36] B.J. Oates. Researching Information Systems and Computing, ( $5^{\text {th }}$ Edition). London, UK: Sage Publications, 2010

[37] A.R. Parathnandh, S. Sing, U. Lalloo, S. Pillay and N. Nadesanreddy. The use of ICT for teaching in poor resource setting. 6th International Conference on Computer Supported Education, CSEDU April, pp. 625-628, 2014.

[38] D. Patel. and H.I. Patel. Blended Learning in Higher Education using MOODLE Open Source Learning Management Tool. International Journal of Advanced Research in Computer Science, Vol 8, No. 5, pp 439-441, 2017.

[39] Y. Perwonegoro A.F.R. and Syafei. Reparing eliademy for e-learning media in English language teaching. Journal of English Language Teaching, Vol 5, No. 1, pp. 296-304, 2016. 
[40] A. Petrovici and E.P. Ciobanu. The lesson Moodle teaching-learning resource with interactive content. In The International Scientific Conference eLearning and Software for Education 21-22 April 2016 Bucharest, Vol 3, pp.110-119. “Carol I” National Defense University, July 2016.

[41] D.R. Queiros and M.R. de Villiers. Online learning in a South African higher education institution: Determining the right connections for the student. The International Review of Research in Open and Distributed Learning, Vol 17, No. 5, pp. 165-185, 2016.

[42] M. Rezai-Rad, R. Vaezi, and F. Nattagh. E-Health Readiness Assessment Framework in Iran. Iranian J Publ Health, Vol 41, No. 10, pp. 43-51, 2012.

[43] M. Sarrab, A.S. Hafedh and A.M. Bader. System quality characteristics for selecting mobile learning applications. Turkish Online Journal of Distance Education. Vol 16, No. 2, pp. 18-28, 2015.

[44] M. Sibanda and S. Donnelly. The impact of E-Learning on student performance: A case study of an entry-level module at a South African University. Mediterranean. Journal of Social Sciences, MCSER Publishing, Vol 5, No. 9, pp. 478-485, 2014.

[45] S.N. Shamsuddin, Abu-Bakar, N.F. Makhtar, W.M. Wan-Isa, A. Rozaimee and N. Yusof. A Framework for Designing Mobile Quranic Memorization Tool Using Multimedia Interactive Learning. Journal of Theoretical and Applied Information Technology, Vol 92, No. 1, pp. 20, 2016.

[46] A. Sheikhtaheri, K. Kimiafar and M. Sarbaz, 2014. Evaluation of system quality of hospital information system: a case study on nurses' experience. In MIE, pp. 960-964.

[47] S. Shorey, A.L. Siew and E. Ang. Experiences of nursing undergraduates on a redesigned blended communication module: A descriptive qualitative study. Nurse education today, Vol 61, pp. 77-82, 2018.

[48] G. Ssekakubo, H. Suleman and G. Marsden. Issues of adoption: have e-learning management systems fulfilled their potential in developing countries?. In Proceedings of the South African Institute of Computer Scientists and Information Technologists Conference on Knowledge, Innovation and Leadership in a Diverse, Multidisciplinary Environment 3-5 October 2011 Cape Town South Africa, pp. 231-238, October 2011.

[49] V. Stantchev, R. Colomo-Palacios, P. Soto-Acosta and S. Misra. Learning management systems and cloud file hosting services: A study on students' acceptance. Computers in Human Behaviour, Vol 31, pp.612-619, 2014.

[50] A. Tarhini, K. Hone, X. Liu and T. Tarhini, 2017. Examining the moderating effect of individual-level cultural values on users' acceptance of E-learning in developing countries: a structural equation modeling of an extended technology acceptance model. Interactive Learning Environments, Vol 25, No. 3, pp. 306-328.

[51] A.T. Weinstein, and D.A. McFarlane, 2017. How libraries can enhance customer service by implementing a customer value mindset. International Journal of Nonprofit and Voluntary Sector Marketing, Vol 22, No. 1, pp. 1-7.

[52] W. Wong and N.N. Huang, 2011. The Effects of E-Learning Systems Service Quality and Users Acceptance on Organisational Learning. International Journal of Business Information, Vol 6, No. 2, pp. 205-225.

[53] N. Zainuddin, R. Idrus, and A.F.M Jamal. Innovative Utilization of the MOODLE in Postgraduate ODL Courses at Universiti Sains Islam Malaysia. In ICEL2016-Proceedings of the 11th International Conference on e-Learning 2-3 June 2016 Kuala Lumpur Malaysia, pp. 157-163. Academic Conferences and publishing limited, 2016.

[54] A. Zancanaro, C.S. Nunes and M.J.C.D.S. Domingues. Evaluation of Free Platforms for Delivery of Massive Open Online Courses (MOOCS). Turkish Online Journal of Distance Education, Vol 18, No. 1, pp. 166-181, 2017.

[55] S.L. Zulu. The impact of project management process quality on construction project performance: a structural equation model (Doctoral dissertation, Heriot-Watt University), 2007. 